\begin{abstract}
Invasive red lionfish (Pterois volitans) have spread rapidly throughout the northern Gulf of Mexico (GOM) partly because of their high growth rate. Red lionfish were collected from the northern GOM across 3 ecological regions from 2012 through 2015. For male and female red lionfish, relationships between weight and total length (TL) were different by ecological region. Males achieved a greater mean weight adjusted for TL (333.6 g [standard error (SE) 3.6]) than females (195.1 $\mathrm{g}$ [SE 3.7]). A subsample of 1607 pairs of sagittal otoliths (from 744 males, 716 females, and 147 fish of unknown or undetermined sex) was used to assign ages. Ages ranged from 0.0 to 4.5 years (mean: 1.4 years), and these estimated ages and the dates of capture for specimens confirm the presence of red lionfish in the northern GOM in 2008, 2 years prior to the first detection of this species there. There were differences in age and growth between sexes within and among ecological regions, with males achieving higher growth rates and larger asymptotic lengths than females (all comparisons: $P<0.01)$. These findings, coupled with other life history information, aid in discerning differences in distribution of red lionfish populations and are essential for creating management plans for mitigation of their effects on ecosystems.
\end{abstract}

\title{
Comparison of age and growth parameters of invasive red lionfish (Pterois volitans) across the northern Gulf of Mexico
}

\author{
Alexander Q. Fogg (contact author) $)^{1,2}$ \\ Joseph T. Evans ${ }^{3}$ \\ Mark S. Peterson ${ }^{1}$ \\ Nancy J. Brown-Peterson ${ }^{4}$ \\ Eric R. Hoffmayer 5 \\ G. Walter Ingram Jr. ${ }^{5}$ \\ Email address for contact author: fogg.alex@gmail.com \\ ${ }^{1}$ Division of Coastal Sciences \\ School of Ocean Science and Engineering \\ University of Southern Mississippi \\ 703 East Beach Drive \\ Ocean Springs, Mississippi 39564 \\ ${ }^{2}$ Okaloosa County Board of County \\ Commissioners \\ Emerald Coast Convention and Visitors Bureau \\ 1540 Miracle Strip Parkway \\ Fort Walton Beach, Florida 32548 \\ ${ }^{3}$ Marine Resource Research Institute \\ South Carolina Department of Natural \\ Resources \\ 217 Fort Johnson Road \\ Charleston, South Carolina 29412 \\ ${ }^{4}$ Center for Fisheries Research and Development \\ School of Ocean Science and Engineering \\ University of Southern Mississippi \\ 703 East Beach Drive \\ Ocean Springs, Mississippi 39564 \\ ${ }^{5}$ Mississippi Laboratories \\ Southeast Fisheries Science Center \\ National Marine Fisheries Service, NOAA \\ 3209 Frederic Street \\ Pascagoula, Mississippi 39567
}

The invasive red lionfish (Pterois volitans) and devil firefish (P. miles) have been reported as established in U.S. waters of the western North Atlantic Ocean and in the Caribbean Sea, and the red lionfish has been found in the Gulf of Mexico (GOM) (Morris and Akins, 2009; Schofield, 2010; Fogg et al., 2017); however, the devil firefish has not yet been detected in the GOM (Johnson et al., 2016). It is difficult to distinguish between these 2 species except through genetic analysis, and data from previous studies are not necessarily separated by species. Therefore, throughout this paper, we use the term lionfish to refer to specimens that are not identified to species but are a potential combination of red lionfish, devil firefish, and hybrids between the 2 species.
Lionfish were first documented in the United States off Dania Beach, on the eastern coast of Florida, in 1985 (U.S. Geological Survey, Nonindigenous Aquatic Species Database, website, accessed December 2015) and later documented in the GOM in 2009 (Aguilar-Perera and Tuz-Sulub, 2010; Nonindigenous Aquatic Species Database, accessed December 2015). By 2012, lionfish were commonly captured in the northern GOM (Fogg et al., 2013), and histological evidence of spawning-capable lionfish in the northern GOM was first observed from fish captured in May 2012 (Brown-Peterson and Hendon, 2013). Efforts to research lionfish species have increased as their invasion has expanded, but most work has focused on the effects of lionfish reflect the position of the National Marine Fisheries Service, NOAA.

Manuscript submitted 31 July 2018.

Online publication date: 3 July 2019.

The views and opinions expressed or implied in this article are those of the 
species on native fish species and coral reef communities (Dahl and Patterson, 2014; Albins, 2015; Benkwitt, 2015; Ingeman and Webster, 2015; Rocha et al., 2015; Acero et al., 2019) and on aspects of landscape-level movements among reef systems and invasion control efforts (Frazer et al., 2012; Green et al., 2014; Tamburello and Côtè, 2015). Results from a recent study indicate that red lionfish have unique morphological functional traits that reduce the theoretical ecological space of 5 coral reef mesopredators of the Caribbean Sea (Rojas-Vélez et al., 2019). However, data are limited for age and growth of lionfish species throughout the geographic range that they have invaded.

Knowledge of weight-length relationships, size and age structure, and growth patterns are important for the successful assessment and management of species. This information can also be used to assess the effects of invasive species on native species and the ecosystems they inhabit. For example, although data such as weight-length relationships are generally useful for quantifying changes in size or age structure that relate to potential overexploitation of a species (Berkeley et al., 2004; Dulvy et al., 2004), such data also could be used as indicators of success in management of invasive species (Pasko and Goldberg, 2014). Additionally, weight-length relationships could be used to examine changes in population structure during post-culling activities or following large-scale disease or environmental perturbation (e.g., an algal bloom). Although a number of studies have reported basic weight and length data for invasive lionfish (Barbour et al., 2011; Fogg et al., 2013; Dahl and Patterson, 2014; Edwards et al., 2014; Sabido-Itzá et al., 2016), few make comparisons between regions or sexes.

Estimations of age and growth relationships for species within invaded geographic ranges are important for describing spatially explicit variation in life history. Larger and older fish tend to affect ecosystems differently than smaller and younger individuals because diet and habitat use can change with age and size (Curtis et al., 2017; Mizrahi et al., 2017; García-Rivas et al., 2018). Age and growth patterns of lionfish vary geographically. Johnson and Swenarton (2016) verified their length-based model outputs with ages determined from a subsample of 100 sectioned otoliths from fish (age 0-3; maximum size of $342 \mathrm{~mm}$ in total length [TL]) captured offshore of Jacksonville, Florida. Additional information from other studies conducted outside of the GOM illustrates this variation. Lionfish captured in Onslow Bay, North Carolina, had a maximum age of 8 years, with more than $90 \%$ of these fish (number of samples examined $[n]=814)<3$ years old (Potts et al., 2010; Barbour et al., 2011). Two red lionfish collected off the coast of South Carolina, at sizes of 352 and $389 \mathrm{~mm}$ TL, were determined to be 5 and 6 years old, respectively (Meister et al., 2005).

Limited data from regions in the GOM and the Caribbean Sea indicate similar variation. Red lionfish collected from the Dry Tortugas in the Florida Keys had a maximum age of 7 years $\left(\right.$ Dubel $\left.^{1}\right)$. Rodríguez-Cortés et al. (2015) provided the

\footnotetext{
${ }^{1}$ Dubel, A. M. 2017. Age structure and growth of lionfish (Pterois volitans): the Dry Tortugas National Park. Internship Rep. 32 , 40 p. Univ. Miami, Miami, FL. [Available from website.]
}

first growth and mortality estimates for the southern region of the GOM (Mexico), although the modeled lengths of red lionfish ( $n=776$; range: $90-389 \mathrm{~mm}$ TL) from that study were not verified by using otoliths. Edwards et al. (2014), using otoliths from 110 male and 128 female lionfish captured off Little Cayman, found a maximum age of only 5 years and confirmed annual annuli formation for fish from that region of the Caribbean Sea. However, no ages determined from analysis of wild-caught lionfish are as old as the ages of lionfish held in captivity (30-33 years; Potts et al., 2010).

Lionfish species have invaded different regions of the GOM and the Caribbean Sea at different times (Schofield, 2010) and can be found in vastly different ecosystems (Barbour et al., 2010; Jud et al., 2011; Claydon et al., 2012; Ruttenberg et al., 2012) and different densities (Green and Côté, 2009; Darling et al., 2011; Dahl and Patterson, 2014). Therefore, we expected that age and growth parameters would vary by location, a notion that Villaseñor-Derbez and Fitzgerald (2019) have since verified. Additionally, rapid growth rates generally lead to successful invasion of an area by a species; therefore, it is important to estimate growth rates (Copp and Fox, 2007). Although age and growth data have been reported for portions of the invaded geographic range, growth of red lionfish could differ between the southern and northern regions of their non-native range (Barbour et al., 2011). Therefore, we hypothesized that the age structure of red lionfish is much younger in the northern GOM than in other invaded regions where they have been established for a longer period. The goal of this study was to determine if differences in weight and length and in age and growth relationships exist by sex or across the northern GOM.

\section{Materials and methods}

Initially, we did not identify our specimens to species, instead putting them in a complex that comprises both Pterois volitans and $P$. miles because it was unknown at the beginning of our study if both species occurred in the GOM (Hamner et al., 2007; Brown-Peterson and Hendon, 2013; Fogg et al., 2013) or if there were hybrids in the GOM. Results from subsequent work, including a study that used specimens we provided for genetic analysis, indicate that the red lionfish is the only species detected to date in the northern GOM (Johnson et al., 2016). Therefore, we identify all specimens that we collected in the northern GOM throughout our study as P. volitans.

From 2012 through 2015, red lionfish were collected opportunistically every month (for details about specimen collection, see Fogg et al., 2017) across 3 ecological regions (or ecoregions) of the northern GOM: southeast (from the Florida Keys north to Anclote Keys, Florida), northeast (from the Anclote Keys north to Mobile Bay, Alabama), and central (west of Mobile Bay to Galveston Bay, Texas; 1 fish was collected west of Galveston Bay) (Fig. 1). Clearly identified, ecologically relevant ecoregions in the GOM and the Caribbean Sea vary and are debated because authors use somewhat different environmental data and quantitative approaches to delineate ecoregions 


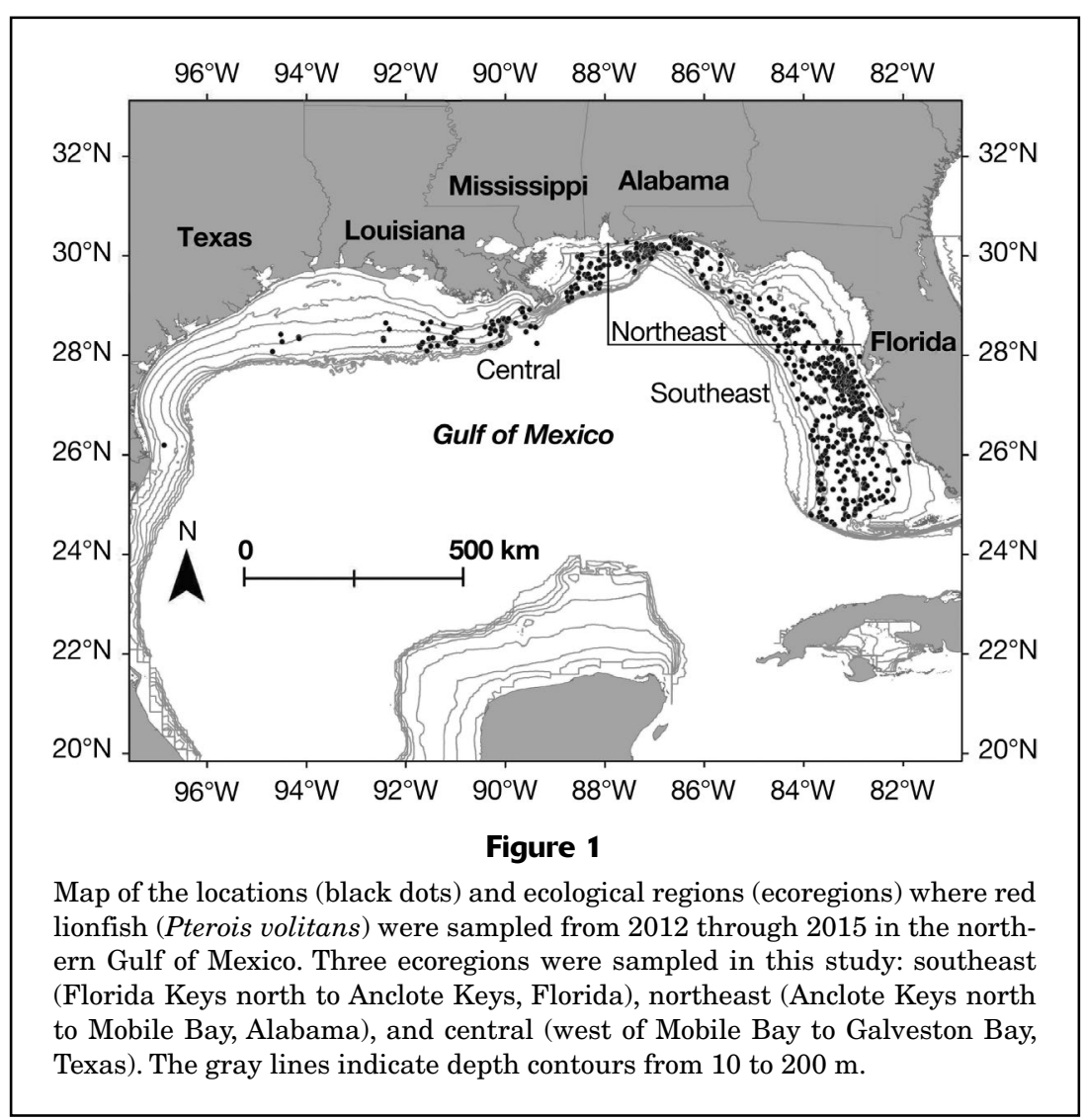

(e.g., Sullivan Sealey and Bustamante, 1999; YáñezArancibia and Day, 2004; Spalding et al., 2007; Robertson and Cramer, 2014). Most ecoregions are identified on the basis of known biogeographic criteria, such as thermal regimes, habitat, floral and faunal assemblage composition, sediment structure, currents and bathymetry, and coastal structural complexity.

The northern tip of the Anclote Keys off the western coast of Florida, for example, has been identified as a point of a north-south ecoregion break (Beck and Odaya, 2001; Beck, 2003; Spalding et al., 2007) in the northern GOM. This boundary between the southeast and northeast ecoregions is used mostly because of the thermal differences between the 2 ecoregions; in the winter months, water temperatures are consistently lower in the northeast ecoregion than in the southeast ecoregion (temperature data were obtained from NOAA's National Data Buoy Center, website). The Mississippi River often is used to divide the northern GOM into east and west ecoregions; however, we follow the ecoregion delineation based on Beck (2003) and Yáñez-Arancibia and Day (2004), dividing our study area into central and northeast ecoregions. Our northeast ecoregion, which is considered the east ecoregion by Beck and Odaya (2001), Beck (2003), and Yáñez-Arancibia and Day (2004), is characterized by less freshwater input, sandier sediments, and enhanced water clarity compared with the central ecoregion where increased freshwater input, lower salinities, and muddy sediment input dominate. The northeast ecoregion is dominated by seagrass meadows, but the central ecoregion is mainly salt marsh (Beck, 2003; Yanez-Aráñcibia and Day, 2004).

Total length, measured in millimeters, and total weight, measured in grams, were recorded, and weight-length relationships were calculated by sex and ecoregion. These data were used to estimate the weight-length power functions. The weight-length data were log transformed (base 10) prior to an analysis of covariance (ANCOVA), with TL as the covariate. An ANCOVA was first completed for each sex separately, comparing the weight-length relationships found across each of the 3 ecoregions. If no significant differences were found across ecoregions, data were pooled and a second ANCOVA was completed to compare weight-length relationships for each ecoregion by sex. If the weight-length relationships for any ANCOVA violated the homogeneity of slopes assumption (parallelism), separate models were used. The estimated marginal means from these analyses were used to make comparisons between sexes of weight adjusted for mean TL. All ANCOVA were completed by using SPSS Statistics ${ }^{2}$, vers. 20 (IBM Corp., Armonk, NY).

The sagittal otoliths were removed from red lionfish, and the left otolith was embedded and sectioned to a $300-\mu \mathrm{m}$ thickness following Secor et al. (1991). Prepared otoliths

\footnotetext{
${ }^{2}$ Mention of trade names or commercial companies is for identification purposes only and does not imply endorsement by the National Marine Fisheries Service, NOAA.
} 


\section{Table 1}

Comparisons of weight-length relationships of red lionfish (Pterois volitans) for each ecological region (ecoregion) sampled in the northern Gulf of Mexico from 2012 through 2015: southeast (Florida Keys north to Anclote Keys, Florida), northeast (Anclote Keys north to Mobile Bay, Alabama), and central (west of Mobile Bay to Galveston Bay, Texas). (A) Regression equations for comparisons by sex within each ecoregion. (B) Pairwise comparisons by sex between ecoregions. Between-sex and between-ecoregion comparisons of weight (W) were evaluated by using analysis of covariance with total length (TL) as the covariate.

$\mathbf{A}$

\begin{tabular}{|c|c|c|c|c|c|}
\hline \multirow[b]{2}{*}{ Ecoregion } & \multicolumn{2}{|r|}{ Male } & \multicolumn{2}{|c|}{ Female } & \multirow[b]{2}{*}{ Comparison } \\
\hline & $n$ & Regression equation & $n$ & Regression equation & \\
\hline Southeast & 857 & $W=2.00 \times 10^{-6}(T L)^{3.34}$ & 671 & $W=1.00 \times 10^{-6}(T L)^{3.44}$ & $F_{1,1528}=12.68, P<0.001$ \\
\hline Northeast & 1181 & $W=3.00 \times 10^{-6}(T L)^{3.26}$ & 1239 & $W=3.00 \times 10^{-6}(T L)^{3.30}$ & $F_{1,2420}=2.32, P=0.128$ \\
\hline Central & 368 & $W=3.00 \times 10^{-6}(T L)^{3.30}$ & 354 & $W=2.00 \times 10^{-6}(T L)^{3.41}$ & $F_{1,722}=6.84, P=0.090$ \\
\hline Pooled & 2406 & $W=3.00 \times 10^{-6}(T L)^{3.29}$ & 2264 & $W=2.00 \times 10^{-6}(T L)^{3.37}$ & $F_{1,4670}=21.96, P<0.001$ \\
\hline
\end{tabular}

B

\begin{tabular}{lll}
\hline Ecoregion comparison & \multicolumn{1}{c}{ Males } & \multicolumn{1}{c}{ Females } \\
\hline Southeast vs. northeast & $F_{1,2038}=8.16, P=0.004$ & $F_{1,1910}=27.72, P<0.001$ \\
Northeast vs. central & $F_{1,1549}=1.42, P=0.223$ & $F_{1,1593}=10.19, P=0.001$ \\
Southeast vs. central & $F_{1,1225}=0.86, P=0.354$ & $F_{1,1025}=0.61, P=0.436$ \\
Pooled ecoregions & $F_{2,2406}=4.17, P=0.015$ & $F_{2,2264}=15.88, P<0.001$
\end{tabular}

were read by 2 independent readers to assign age information. The average percent error (APE) between readers was estimated following Vanderkooy and Guindon-Tisdel ${ }^{3}$. Otolith sections had 2 distinct band types, with the opaque bands formed during slow growth periods and the translucent bands formed during periods of faster growth (see fig. 7 in Fogg, 2017; Vanderkooy and Guindon-Tisdel ${ }^{3}$ ). Any otoliths with discrepancies in ages between the 2 readers were reexamined, and if a consistent age could not be determined for an otolith, it was removed from analysis. Following agreement on an age, marginal increment analysis was conducted by measuring marginal increments (to the nearest $0.001 \mathrm{~mm}$ ) and comparing them to the width of the previous complete annuli by using the following equation (Tanaka et al., 1981): $C=W_{\mathrm{n}} / W_{\mathrm{n}-1}$, where $C$ is the index of completion, $W_{\mathrm{n}}$ is the width of the marginal increment, and $W_{n-1}$ is the width of the previous complete annulus. This method was used to confirm the periodicity of annuli formation. To determine ages when the most recent band was incomplete (indicating only a partial year of growth), we assigned one of 4 otolith margin codes to the incomplete outer ring, as viewed under transmitted light (Vanderkooy and Guindon-Tisdel ${ }^{3}$ ): 1 (opaque), 2 (1/3 translucent), 3 (1/2 translucent), and 4 (2/3 translucent). Each marginal code equals 0.25 years.

Because our sample collections lacked smaller fish ( $<100 \mathrm{~mm}$ TL), a truncated normal distribution was used to fit a 3-parameter von Bertalanffy growth curve to the

\footnotetext{
${ }^{3}$ VanderKooy, S., and K. Guindon-Tisdel. 2003. A practical handbook for determining the age of Gulf of Mexico fishes. Gulf States Mar. Fish. Commission Publ. 111, 109 p. [Available from website.]
}

age data, and separate model parameters were determined for each sex and ecoregion for comparison (Diaz et al. ${ }^{4}$ ). Because the von Bertalanffy growth curve is nonlinear, a sum of squares reduction test (Schabenberger and Pierce, 2002) was used with statistical software SAS (vers. 9.4; SAS Institute, Inc., Cary, NC), instead of a traditional analysis of variance to determine if there were differences in growth between ecoregions and sexes by comparing nonlinear trends between groups $(\alpha=0.05)$. The sum of squares reduction test was conducted by fitting a full and reduced model to the data. The test statistic $(F)$ was calculated following this equation: $F=[(S S R R-S S R F) /(D F R R-D F R F)] /$ $M S R F$, where $S S R R$ and $S S R F$ are the residual sums of squares from the reduced and full model, respectively, $D F R R$ and DFRF are the residual degrees of freedom for the reduced and full model, respectively, and $M S R F$ is the mean sum of squares from the full model. This test evaluates the $S S R F$ when the $S S R R$ is removed from the model.

\section{Results}

The slopes of the weight-length relationships for male and female red lionfish were significantly different within the southeast ecoregion and did not differ in the 2 other ecoregions (ANCOVA: $F_{1,1528}=12.68, P<0.001$ ) (Table $1 \mathrm{~A}$, Fig. 2). The weight-length relationships from data pooled

\footnotetext{
${ }^{4}$ Diaz, G. A., C. E. Porch, and M. Ortiz. 2004. Growth models for red snapper in U.S. Gulf of Mexico waters estimated from landings with minimum size limit restrictions. Southeast Data Assessment and Review SEDAR7-AW-01, 13 p. [Available from website.]
} 


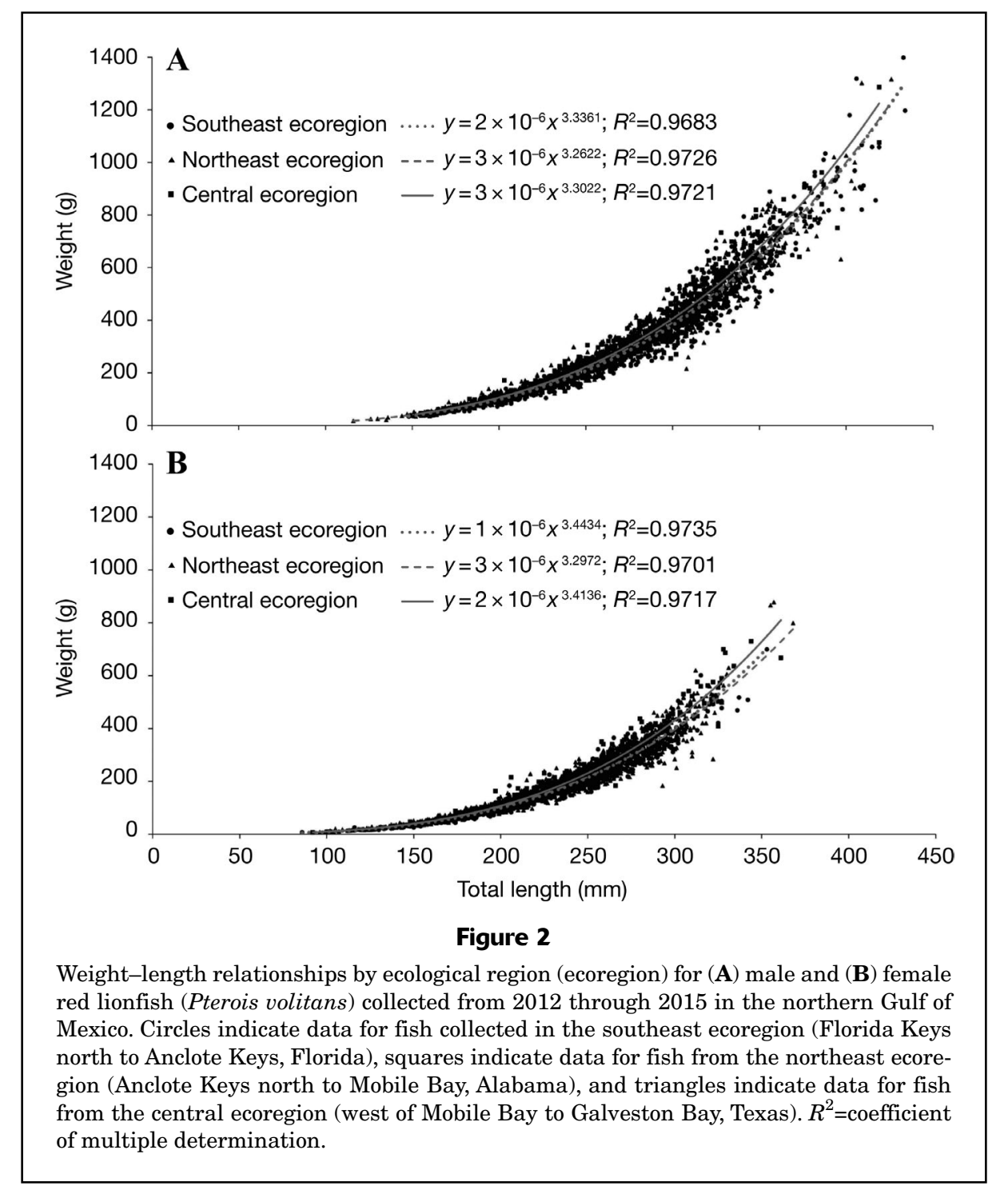

across all 3 ecoregions for red lionfish had significantly different slopes by sex (ANCOVA: $F_{1,4670}=21.96, P<0.001$; Table 1A), indicating that females had a steeper weightlength relationship than males (Table 1A, Fig. 3) and, therefore, had a greater weight at a given TL. Pairwise comparisons of weight-length relationships by ecoregion (Table 1B) revealed a significant difference for male red lionfish only between the southeast and northeast ecoregions (ANCOVA: $F_{1,2038}=8.16, P=0.004$; Table 1B); whereas, significant differences were observed for female red lionfish in all comparisons between ecoregions except between the southeast and central ecoregions (ANCOVA: $F_{1,1025}=0.61, P=0.436$; Table $\left.1 \mathrm{~B}\right)$. However, in all ecoregions, males attained larger weights when adjusted for TL than females (Table 2). For a number of comparisons of ecoregions (Table 1B), weight-length relationships were significantly different, but the differences in weight were minimal on the basis of their estimated marginal means adjusted for TL (females: $18.21 \mathrm{~g}$; males: $22.75 \mathrm{~g}$; Table 2), and male red lionfish achieved a greater mean weight (333.62 g [standard error (SE) 3.58]) compared to females (195.13 [SE 3.69]) (Table 2).

From the 4250 pairs of otoliths that were extracted, a subsample of 1607 pairs of otoliths (744 males, 716 females, and 147 fish of unknown or undetermined sex) were randomly selected and processed from red lionfish ranging in size from 81 to $434 \mathrm{~mm}$ TL. Age agreement was reached for 1412 pairs of otoliths $(87.9 \%)$ from that subsample. The APE for analysis of otoliths from the southeast ecoregion was 7.7, the APE for the northeast ecoregion was 14.2, and the APE for the central ecoregion was 11.7. With analysis results from all 3 ecoregions pooled, the APE between readers was 12.1. Annual increment formation was confirmed by using marginal increment analysis, with marginal increment widths most complete in May and gradually decreasing until a minimum index of completion 


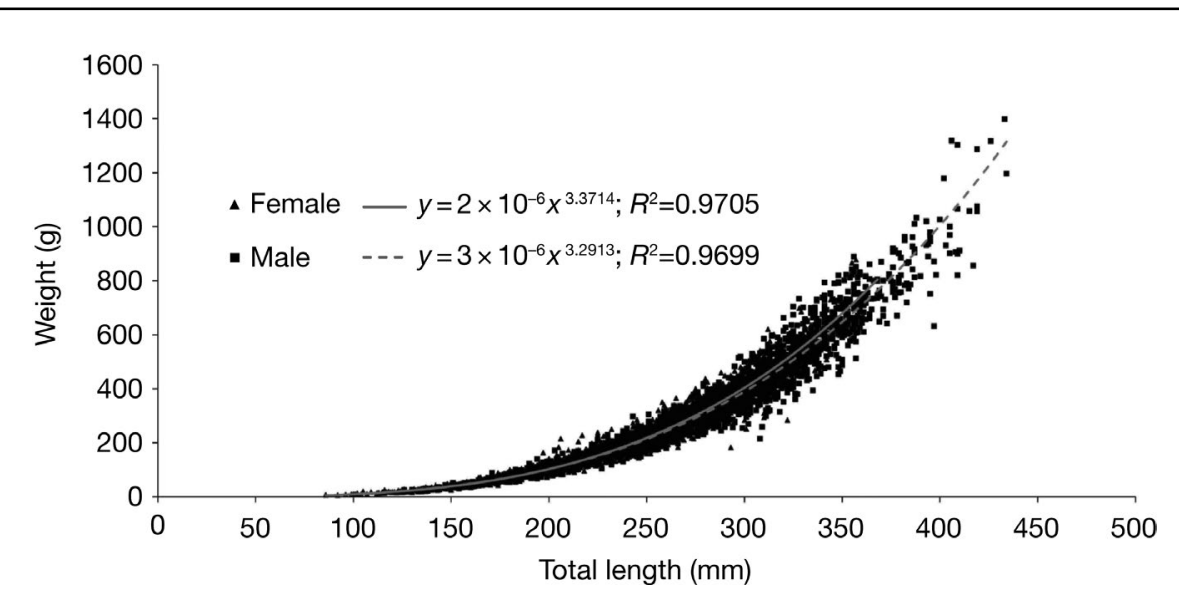

Figure 3

Weight-length relationships for male (squares) and female (triangles) red lionfish (Pterois volitans) collected from 2012 through 2015 in the northern Gulf of Mexico. Data are pooled for all sampled ecological regions. $R^{2}=$ coefficient of multiple determination.

\begin{tabular}{|c|c|c|c|}
\hline \multicolumn{4}{|c|}{ Table 2} \\
\hline \multicolumn{4}{|c|}{$\begin{array}{l}\text { Estimated marginal mean weight, in grams and adjusted for total length in millime- } \\
\text { ters, for invasive red lionfish (Pterois volitans) collected from } 2012 \text { through } 2015 \text { in } \\
3 \text { ecological regions (ecoregions) in the northern Gulf of Mexico: southeast (Florida } \\
\text { Keys north to Anclote Keys, Florida), northeast (Anclote Keys north to Mobile Bay, } \\
\text { Alabama), and central (west of Mobile Bay to Galveston Bay, Texas). Estimates are } \\
\text { given for females, males, and sexes pooled with standard errors of the mean (SEs) in } \\
\text { parentheses. }\end{array}$} \\
\hline Sex & Ecoregion & $n$ & Estimated weight (SE) \\
\hline Female & Southeast & 668 & $187.98(1.69)$ \\
\hline Female & Northeast & 1227 & $193.88(1.22)$ \\
\hline Female & Central & 348 & $206.19(2.35)$ \\
\hline Female & Pooled & 2243 & $195.13(3.69)$ \\
\hline Male & Southeast & 844 & $325.20(2.36)$ \\
\hline Male & Northeast & 1101 & $334.50(2.01)$ \\
\hline Male & Central & 346 & $347.95(3.61)$ \\
\hline Male & Pooled & 2291 & $333.62(3.58)$ \\
\hline Pooled & Southeast & 1512 & $258.75(4.79)$ \\
\hline Pooled & Northeast & 2328 & $253.52(3.86)$ \\
\hline Pooled & Central & 694 & $294.96(7.07)$ \\
\hline
\end{tabular}

was reached in October and November, indicating the beginning of annuli formation (Fig. 4). Ages of red lionfish ranged from 0.5 to 4.5 years (Fig. 5), with $93 \%$ of aged red lionfish $<2$ years old. The smallest and youngest specimen collected in this study was a $81-\mathrm{mm}$-TL, 0.5-yearold fish of unknown sex, and the oldest specimen was a 380-mm-TL, 4.5-year-old male. The largest fish collected was a 434-mm-TL male, but its estimated age was 3.5 years. The state record for the longest lionfish caught in the northern GOM (459 mm TL) was for a fish collected off Pensacola, Florida (record available from website).

There were significant differences in age and growth parameters by sex and by ecoregion (all comparisons: $P<0.001$; for comparisons of modeled estimates with the sum of squares reduction test, see Table 3; for observed values, see Figure 6). Female red lionfish from the southeast ecoregion had the highest growth rate $(K)$ and asymptotic length $\left(L_{\infty}\right)$ and achieved a greater length at age than 


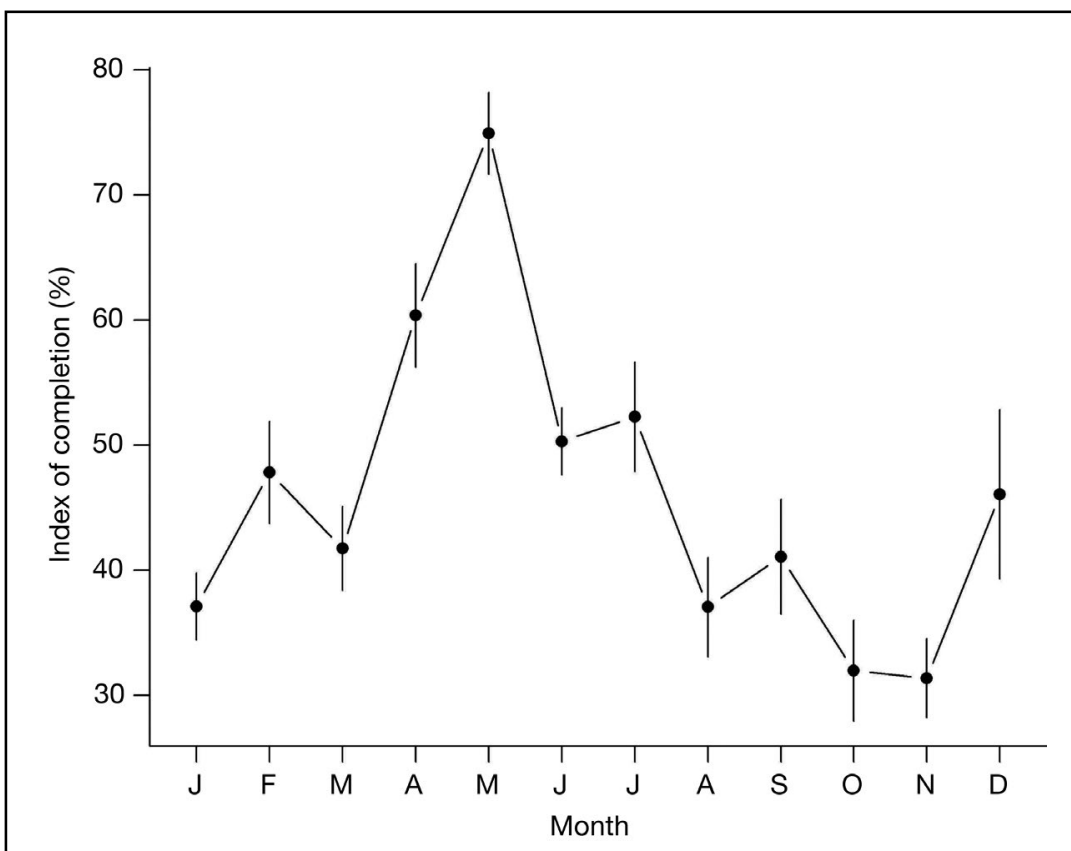

Figure 4

Plot of the mean index of marginal increment completion by month for red lionfish (Pterois volitans) collected from 2012 through 2015 in the northern Gulf of Mexico. Number of samples ranged from 30 in December to 192 in June. Vertical lines indicate standard errors of the mean.

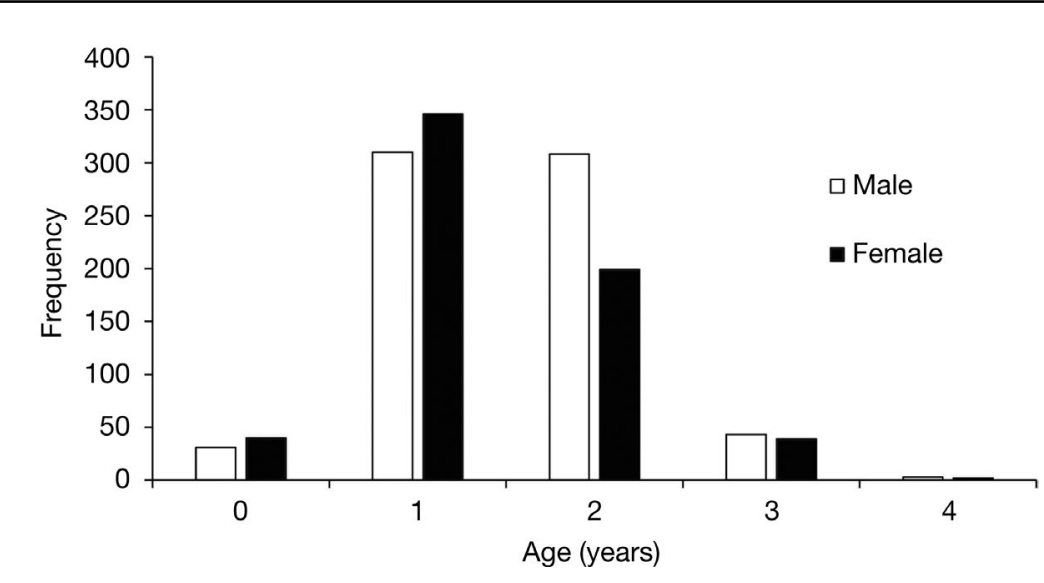

Figure 5

Age-frequency distribution of male and female red lionfish (Pterois volitans) collected from the northern Gulf of Mexico from 2012 through 2015.

females in the other 2 ecoregions (Table 3A, Fig. 6A). Similarly, male red lionfish from the southeast ecoregion also had the highest $K$ and $L_{\infty}$ values and achieved a greater length at age than males in the other 2 ecoregions (Table 3A, Fig. 6B). Data pooled by sex revealed a similar pattern, with the highest $K$ and $L_{\infty}$ values estimated for red lionfish from the southeast ecoregion and lowest values estimated for red lionfish from the central ecoregion (Table 3A, Fig. 6C). Separate comparisons were made by sex for each ecoregion, with male red lionfish achieving higher $K$ and $L_{\infty}$ values than females in all 3 ecoregions (all comparisons: $P<0.05$; Table 3B, Fig. 7, A-C). Model 


\section{Table 3}

Estimates of von Bertalanffy growth curve parameters for invasive red lionfish (Pterois volitans) collected from 2012 through 2015 in 3 ecological regions (ecoregions) in the northern Gulf of Mexico: southeast (SE; Florida Keys north to Anclote Keys, Florida), northeast (NE; Anclote Keys north to Mobile Bay, Alabama), and central (C; west of Mobile Bay to Galveston Bay, Texas). The parameters are growth rate $(K)$, asymptotic length $\left(L_{\infty}\right.$, given in millimeters in total length), and theoretical age when the length is zero $\left(t_{0}\right)$. (A) Comparisons among ecoregions by sex. (B) Comparisons between sexes by ecoregion. A sum of square reduction test was used to determine differences in growth between ecoregions and sex by comparing nonlinear trends between groups ( $\alpha=0.05$ ).

A

\begin{tabular}{|c|c|c|c|c|c|c|c|c|c|}
\hline \multirow[b]{2}{*}{ Parameter } & \multicolumn{3}{|c|}{ Pooled } & \multicolumn{3}{|c|}{ Female } & \multicolumn{3}{|c|}{ Male } \\
\hline & $\mathrm{SE}$ & $\mathrm{NE}$ & $\mathrm{C}$ & $\mathrm{SE}$ & $\mathrm{NE}$ & $\mathrm{C}$ & $\mathrm{SE}$ & $\mathrm{NE}$ & $\mathrm{C}$ \\
\hline$K$ & 0.569 & 0.544 & 0.539 & 0.574 & 0.549 & 0.542 & 0.576 & 0.547 & 0.543 \\
\hline$L_{\infty}$ & 423.0 & 393.0 & 389.0 & 382.0 & 366.8 & 360.9 & 426.0 & 394.4 & 390.7 \\
\hline \multirow[t]{2}{*}{$t_{0}$} & -0.155 & -0.079 & -0.341 & -0.165 & -0.089 & -0.350 & -0.170 & -0.086 & -0.354 \\
\hline & \multicolumn{3}{|c|}{$F_{12,1412}=27.143, P<0.001$} & \multicolumn{3}{|c|}{$F_{12,626}=7.303, P<0.001$} & \multicolumn{3}{|c|}{$F_{12,695}=12.606, P<0.001$} \\
\hline
\end{tabular}

$\mathbf{B}$

\begin{tabular}{|c|c|c|c|c|c|c|c|c|}
\hline \multirow[b]{2}{*}{ Parameter } & \multicolumn{2}{|c|}{ Southeast } & \multicolumn{2}{|c|}{ Northeast } & \multicolumn{2}{|c|}{ Central } & \multicolumn{2}{|c|}{ Pooled } \\
\hline & Male & Female & Male & Female & Male & Female & Male & Female \\
\hline$K$ & 0.576 & 0.574 & 0.547 & 0.549 & 0.543 & 0.542 & 0.550 & 0.508 \\
\hline$L_{\infty}$ & 426.0 & 382.0 & 394.4 & 366.8 & 390.7 & 360.9 & 405.2 & 368.4 \\
\hline$t_{0}$ & -0.170 & -0.165 & -0.086 & -0.089 & -0.354 & -0.350 & 0.414 & -0.482 \\
\hline & \multicolumn{2}{|c|}{$F_{8,453}=2.412, P=0.008$} & \multicolumn{2}{|c|}{$F_{8,489}=2.012, P=0.030$} & \multicolumn{2}{|c|}{$F_{8,379}=2.362, P=0.010$} & \multicolumn{2}{|c|}{$F_{8,1321}=16.226, P<0.00$} \\
\hline
\end{tabular}

parameters determined from data pooled across all 3 ecoregions indicate that males also had higher $K$ and $L_{\infty}$ values than females (Table 3B, Fig. 7D).

\section{Discussion}

The results of this study reveal significant ecoregion- and sex-specific patterns in age, growth, and weight-length relationships of red lionfish. The $K$ values of red lionfish collected from the southeast ecoregion were higher than those of red lionfish from the northeast and central ecoregions. Although it was expected that $K$ values would be greater for the red lionfish collected in the southeast ecoregion, the $L_{\infty}$ values of many fish species are usually lower in the more southern regions of their geographic range than in the more northern regions (Boehlert and Kappenman, 1980) because fish species from northern latitudes typically achieve larger sizes than fish species from southern latitudes (Lindsey, 1966). The observed anomaly in $L_{\infty}$ values may also be a result of density-dependent growth, as has been documented in invasive red lionfish on small artificial reefs in the Bahamas (Benkwitt, 2013). Red lionfish collected from the northeast ecoregion in particular came from much smaller and isolated artificial and natural reefs and were found in much higher densities compared with densities observed on the reefs in the southeast ecoregion (senior author, unpubl. data).
The results of our marginal increment analysis indicate that annuli on otoliths from red lionfish were most complete in the spring (March-May) and least complete in the fall (September-October), a finding similar to that for another scorpaenid, the native blackbelly rosefish (Helicolenus dactylopterus), off the coasts of North and South Carolina (White et al., 1998). In contrast, black scorpionfish (Scorpaena porcus) from the Adriatic Sea had their most complete annuli in the late summer (JulySeptember; La Mesa et al., 2010). Comparable thermal regimes between the northern GOM and North and South Carolina likely are the reason for the similar trends in annuli formation between invasive red lionfish and native blackbelly rosefish; similar trends have been documented in red snapper (Lutjanus campechanus) from similar thermal regimes (Nelson and Manooch, 1982). Black scorpionfish from the Adriatic Sea likely have delayed annuli completion compared with the annuli formation of the red lionfish in our study because of the relatively cooler sea-surface temperatures $\left(\sim 11^{\circ} \mathrm{C}\right)$ that that they experience in the spring. Sea-surface temperatures in the Adriatic Sea warm to above $20^{\circ} \mathrm{C}$ in July (La Mesa et al., 2010), similar to sea-surface temperatures observed in March in the northern GOM. Therefore, water temperature may drive annuli completion in these species, as has been reported for other species and regions (Pearson, 1996).

Age estimation was challenging for some red lionfish in our study, with an APE of 12.1 between readers for 


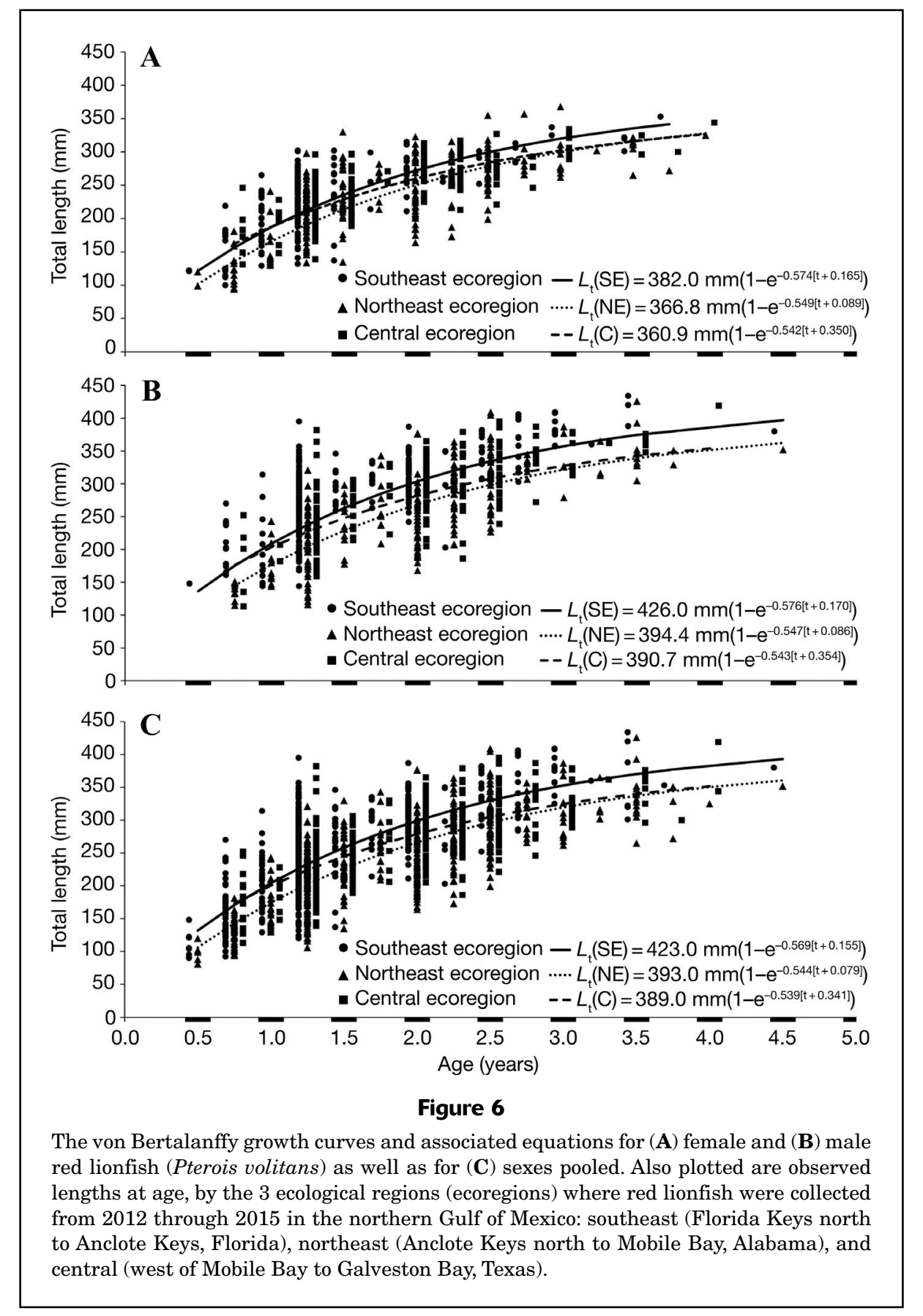

otoliths from fish from all ecoregions pooled. This value is similar to the APE of 7 reported for analysis of otoliths from fish collected off northeast Florida (Johnson and Swenarton et al., 2016). However, all of our APE values are low compared with those of Edwards et al. (2014), who reported an APE of 58 between readers for lionfish collected in the Caribbean Sea. Differences in regional age determination may be expected because annuli in lionfish collected in tropical waters are likely to be more difficult to distinguish than annuli in lionfish living in more temperate regions. Lionfish in tropical waters likely have relatively consistent growth because of minimal variation in water temperatures, and fish in temperate waters experience periods of slow and fast growth (Pitcher and Hart, 1982).

The age of red lionfish from the northern GOM ranged from 0 to 4.5 years $(\overline{\mathrm{x}}=1.35)$, ages that are markedly lower than the maximum reported age of 30-33 years for a specimen held in an aquarium (Potts et al., 2010). Interestingly, the oldest age estimated in this study was 4.5 years 


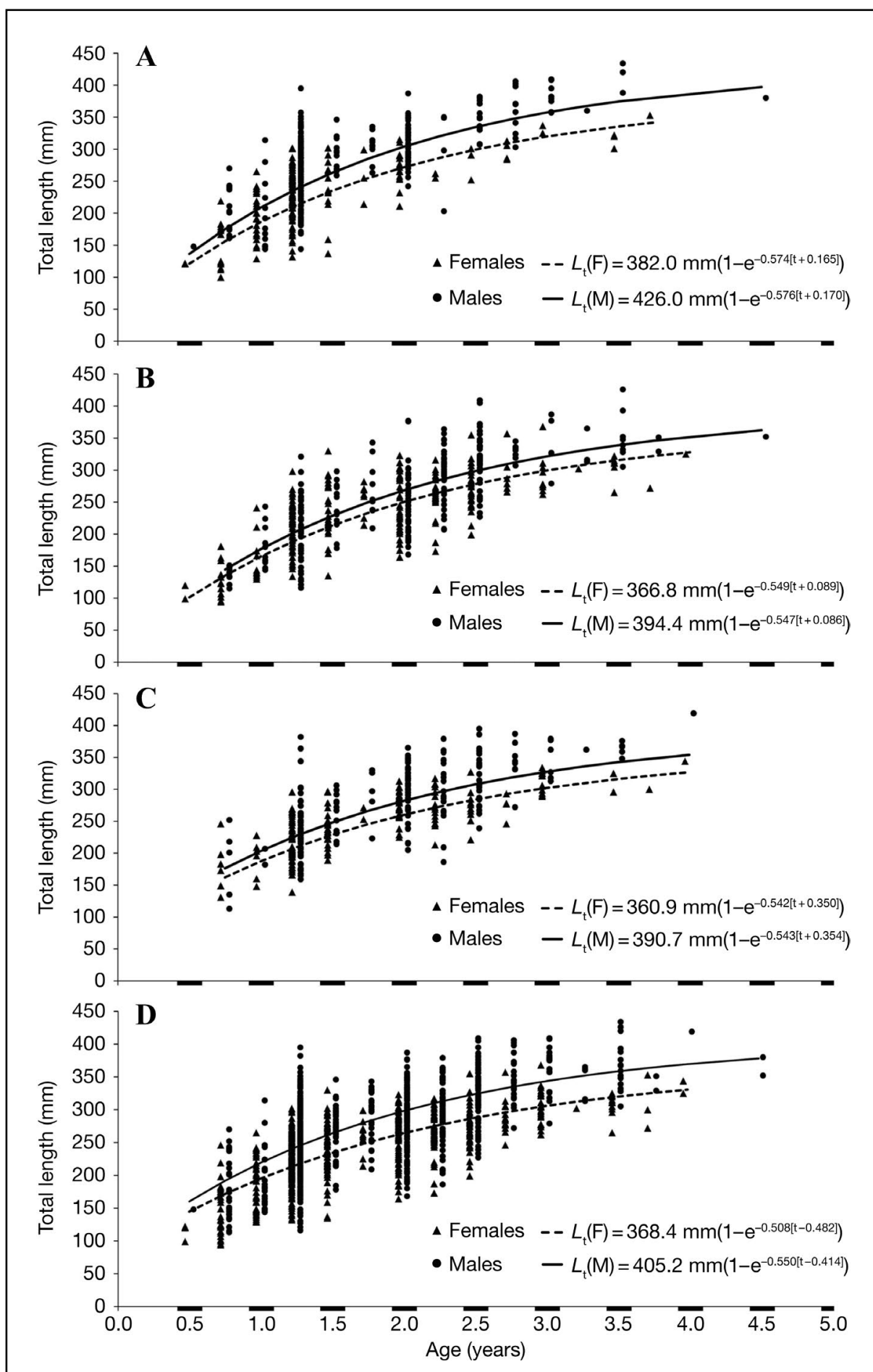

Figure 7

The von Bertalanffy growth curves and associated equations for red lionfish (Pterois volitans). Also plotted are observed lengths at age for female (triangles) and male (squares) red lionfish collected from 2012 through 2015 in the northern Gulf of Mexico, by ecological region (ecoregion), (A) southeast (Florida Keys north to Anclote Keys, Florida), (B) northeast (Anclote Keys north to Mobile Bay, Alabama), and (C) central (west of Mobile Bay to Galveston Bay, Texas), as well as for (D) all ecoregions pooled. 
for a fish collected in November 2012, and the data from our study confirm the presence of red lionfish in the northern GOM as early as 2008, 2 years prior to the first detection in the region in 2010. Edwards et al. (2014) also found a single lionfish (Pterois sp.) with an estimated age that indicates it was present in the Caribbean Sea before the first detection off Little Cayman in 2010. Such delays in documented detections are expected because invasive species often are not detected immediately after introduction because of lag times associated with species expansion (Crooks and Soulé, 1999).

Age distribution of marine fish species is an important factor for assessing the health of a population (Berkeley et al., 2004). Typically, an established, healthy population will exhibit a "well-balanced" age structure (Brunel and Piet, 2013) with numerous larger, older individuals. In the northern GOM, $93 \%$ of red lionfish in our study were $\leq 2$ years old in all 3 ecoregions. Similar results have been reported off Little Cayman (Edwards et al., 2014) and in the Atlantic Ocean off northeast Florida (Johnson and Swenarton, 2016) and North Carolina (Barbour et al., 2011 ), where the majority ( $>90 \%$ ) of lionfish were $\leq 3$ years old. The higher proportion of fish between the ages of 2 and 3 years found in Little Cayman and off northeast Florida and North Carolina is likely the result of lionfish having invaded those locations earlier than the northern GOM (Schofield, 2010).

Although red lionfish can live much longer than what has been described in this study and in studies in other invaded geographic areas, the truncated age-class distribution observed in this study is a further indication that the population of red lionfish in the northern GOM may still be stabilizing in the region because older individuals are not present or not captured. Red lionfish from the southern GOM that were aged in 2012 appeared to be much younger, with age and growth parameters that were much lower than those reported for this study and previous studies (Rodríguez-Cortés et al., 2015). This difference in age structure is likely a result of red lionfish being collected within the first 2 years of their invasion in the southern GOM. The difference also could be due to aging techniques: we determined age on the basis of otolith analysis, but Rodríguez-Cortés et al. (2015) estimated ages on the basis of size-frequency analysis that was not verified by using otoliths. It is important to now establish up-todate region- and sex-specific age and growth parameters so that, in the future when the invasion of red lionfish theoretically has stabilized across the region (Benkwitt et al., 2017; Côté and Smith, 2018), the same parameters can be estimated to evaluate the success of the invasion.

There was an inconsistent pattern of differences in weight-length relationships among ecoregions with only males in the southeast ecoregion being heavier per length than males in the northeast ecoregion. In contrast, differences were found in females in all pairwise comparisons between ecoregions, except for the comparison of the southeast and central ecoregions. Overall, weight-length relationships based on data pooled for males and females and on estimated marginal means adjusted for TL indicate minor differences in weight among ecoregions: $18.21 \mathrm{~g}$ for females and $22.75 \mathrm{~g}$ for males.

Differences in weight-length relationships of lionfish have been reported throughout the range of the invasion among regions that are larger than the ecoregions used in our study (Suppl. Table). Some published comparisons of weight-length relationships have been based on data pooled across a range of locations within the sampled region (Barbour et al., 2011; Edwards et al., 2014; Sabido-Itzá et al., 2016), and the relationships derived from those pooled data differ from those presented here for the northern GOM. Another study compared weightlength data pooled by year, reporting a significant difference between the first and last year (2011-2013) (Dahl and Patterson, 2014). In contrast, Benkwitt et al. (2017) documented no changes in size structure in lionfish from the Bahamas over a 10-year period. Recently, Pusack et al. (2016) reported that red lionfish in their native range grow at a slower rate and achieve smaller maximum sizes than those in the range of their invasion. Finally, lionfish in the range they have invaded may be less susceptible to predation because of their larger size and would also be able to consume larger prey items (see review in Côté and Smith, 2018).

In this study, male red lionfish found in the northern GOM achieved greater weight and length than females. In contrast, results from early work in the northern GOM (Fogg et al., 2013) indicate no significant differences in weight-length relationships by sex for red lionfish. One explanation for these differences between studies may be that the data from Fogg et al. (2013) came from early in the invasion and, therefore, likely had not yet reached an asymptotic value. Although von Bertalanffy growth parameters were not reported by sex in other age and growth studies on invasive lionfish species (e.g., Potts et al. 2010; Barbour et al. 2011; Rodríguez-Cortés et al. 2015; Johnson and Swenarton 2016), age and growth and weight-length data quantified in our study confirm that sexual dimorphism exists with males growing larger and faster than females. Sexual dimorphic growth was documented also for invasive lionfish in Little Cayman by using otolith analysis, but weight-length relationships were not evaluated (Edwards et al., 2014). Males in our study achieved a greater length-at-age than females and, similar to males examined by Edwards et al. (2014), had significantly larger $K$ and $L_{\infty}$ values than females. Males of the related scorpeanid species, blackbelly rosefish, also appear to grow faster and slightly larger than females (White et al., 1998). In contrast, female black scorpionfish, native to the eastern Atlantic Ocean, Mediterranean Sea, and Black Sea, attain larger sizes than males (Bilgin and Çelik, 2009).

The differences observed between male and female red lionfish in age and growth and in weight-length relationships are likely a result of the greater resources that females allocate to reproductive output (Gadgil and Bossert, 1970). Female red lionfish mature in their first year of life and are capable of reproducing every few days during 11 months of the year (Fogg et al., 2017). These elevated and constant reproductive rates likely result in more 


\section{Table 4}

Estimates of von Bertalanffy growth curve parameters, with sexes pooled, for invasive red lionfish (Pterois volitans) collected from 2012 through 2015 in 3 ecological regions (ecoregions) in the northern Gulf of Mexico: southeast (Florida Keys north to Anclote Keys, Florida), northeast (Anclote Keys north to Mobile Bay, Alabama), and central (west of Mobile Bay to Galveston Bay, Texas). The parameters are growth rate $(K)$, asymptotic length $\left(L_{\infty}\right.$, given in millimeters in total length [TL]), and theoretical age when the length is zero $\left(t_{0}\right)$. Because of truncated data sets (i.e., a lack of red lionfish $<100 \mathrm{~mm}$ TL), a sum of squares reduction test was used to compare model parameters between all ecoregions and sexes. All comparisons were significantly different $(P<0.01)$. For comparison, parameters pooled by sex are included for specimens from North Carolina (Barbour et al., 2011), Little Cayman (Edwards et al., 2014), Florida Keys (Swenarton et al., 2016), northeast (NE) Florida (Johnson and Swenarton et al., 2016), and Yucatan, Mexico (Rodríguez-Cortés et al., 2015).

\begin{tabular}{|c|c|c|c|c|c|c|c|c|c|}
\hline \multirow[b]{2}{*}{ Parameter } & \multicolumn{4}{|c|}{ Northern Gulf of Mexico } & \multirow{2}{*}{$\begin{array}{c}\text { North } \\
\text { Carolina }\end{array}$} & \multirow{2}{*}{$\begin{array}{c}\text { Little } \\
\text { Cayman }\end{array}$} & \multirow{2}{*}{$\begin{array}{c}\text { Florida } \\
\text { Keys }\end{array}$} & \multirow{2}{*}{$\begin{array}{c}\mathrm{NE} \\
\text { Florida }\end{array}$} & \multirow{2}{*}{$\begin{array}{c}\text { Yucatan, } \\
\text { Mexico }\end{array}$} \\
\hline & Southeast & Northeast & Central & Pooled & & & & & \\
\hline$L_{\infty}$ & 423.0 & 393.0 & 389.0 & 400.2 & 425.2 & 349.0 & 411.0 & 448.0 & 420.0 \\
\hline$K$ & 0.569 & 0.544 & 0.539 & 0.560 & 0.470 & 0.420 & 0.700 & 0.470 & 0.880 \\
\hline$t_{0}$ & -0.155 & -0.079 & -0.341 & -0.210 & -0.500 & -1.010 & 0.000 & 0.000 & -0.107 \\
\hline
\end{tabular}

energy shunted to reproduction than to growth; therefore, growth in female red lionfish is reduced upon maturation. This trade-off of reduced growth in females as the energy is redirected to reproduction has been described in numerous fish species (Reznick, 1983; Roff, 1983; Parker, 1992).

Another potential reason that males grow larger than females is that males need to increase their chances of success in male rivalries and physical combat and, therefore, their opportunities for mating (Shine, 1989). Evidence of combat between large red lionfish (>350 mm TL, presumably males) has been observed in the northern GOM in the form of abrasions across the body. Recently, agonistic behavior between 2 large lionfish (Pterois spp.) has been observed and documented in Honduras (Fogg and Faletti, 2018).

Growth rates and other life history traits vary by region in other marine fish species (Choat and Axe, 1996; Ruttenberg et al., 2005). The $K$ value for red lionfish in the northern GOM is greater than that reported for fish from Little Cayman (Edwards et al., 2014), North Carolina (Barbour et al., 2011), and northeast Florida (Johnson and Swenarton, 2016), although $K$ values reported for fish from the Florida Keys (Swenarton et al., 2015) and Yucatan, Mexico (Rodríguez-Cortés et al., 2015), were much greater than those in all other studies (Table 4 ). The higher $K$ value observed in the northern GOM could explain why densities of red lionfish are higher there than anywhere else in the geographic range that they have invaded (Dahl and Patterson, 2014). The pattern for age and growth of red lionfish in the northern GOM appears to be most similar to that of lionfish from the Atlantic Ocean off northeast Florida and North Carolina (Table 4). Similarities and differences in age and growth among studies could, in part, be driven by environmental thermal regimes (Lyons et al., 2017; Barker et al., 2018) in addition to other biological and ecological factors (South et al., 2017). However, age and growth will need to be reevaluated in the future because our study examined samples collected early in the invasion of the northern GOM region.
Age and growth data are important to assess potential changes to the population structure of red lionfish that result from implementation of management plans, disease events, and environmental incidents such as an algal bloom. For example, Chagaris et al. (2017) modeled how potential strategies for management of lionfish may affect several recreationally and commercially important native fish species on the West Florida Shelf. The age and growth relationships of lionfish used in their model were based on fish from outside of the region of the West Florida Shelf and, therefore, may not have correctly reflected population dynamics. Moreover, other management plans from agencies around the invaded region specifically mention the need for regional age and growth data (Morris ${ }^{5}$; $\mathrm{ANSTF}^{6}$; Johnston et al., 2015), and these plans noted the need for ongoing research. Accurate and region-specific weight-length, age, and growth data are vital for developing age-structured population models that can be used to evaluate potential effects of targeted removals on the red lionfish population (Barbour et al., 2011) and the potential population-level effects of large-scale disease for red lionfish and devil firefish (Harris et al. ${ }^{7}$ ). These data can also be applied to behavioral studies for which only size information is available (e.g., Garcia-Rivas et al., 2018).

Graham and Fanning (2017) reviewed management plans for invasive lionfish species in the Caribbean Sea, but research updates are needed so that future management

\footnotetext{
${ }^{5}$ Morris, J. A., Jr. (ed.). 2012. Invasive lionfish: a guide to control and management. Gulf Caribb. Fish. Inst., Spec. Publ. Ser. 1, $113 \mathrm{p}$. [Available from website.]

${ }^{6}$ ANSTF (Aquatic Nuisance Species Task Force). 2014. National invasive lionfish prevention and management plan, 48 p. Prepared by the Invasive Lionfish Control Ad-hoc Committee of the ANSTF. [Available from website.]

${ }^{7}$ Harris, H. E., A. Q. Fogg, R. P. E. Yanong, S. Frasca Jr., T. Cody, T. B. Waltzek, and W. F. Patterson III. 2018. First report of an emerging ulcerative skin disease in invasive lionfish. Univ. Fla., Inst. Food Agric. Sci., Ext. Data Inf. Source (EDIS) FA209, 7 p. [Available from website.]
} 
activities, including local "culling" programs (Green et al., 2017; Mizrahi et al., 2017), lead to more accurate forecasting (Johnston et al., 2017) and effective regional management. Information from regional demographic data sets, coupled with identification of spatial and temporal patterns in the harvest vulnerability of older and larger lionfish, can be used to identify regions or seasons that need better protection or regulation (Zhou et al., 2010; Tobin et al., 2013). Data from this study can inform development of region-specific management strategies for controlling the invasion of lionfish in the GOM. This study provides the first regional estimates of life history parameters for red lionfish in the northern GOM, where populations of this invasive species appear to be not only established but also expanding their range (Dahl and Patterson, 2014; Dahl et al., 2016; Fogg et al., 2017). Life history information provided here can be incorporated into studies of competition between lionfish and reef fish species (see Rojas-Vélez et al., 2019) that will enhance management decision-making and stock assessments.

\section{Acknowledgments}

We thank Coast Watch Alliance and the volunteer divers and fishermen for their financial and logistical support. We also thank the undergraduate interns sponsored by the Marine Education Center at the Gulf Coast Research Laboratory, University of Southern Mississippi, for assistance in processing red lionfish. Additional travel and research support was provided by the Gulf and Caribbean Fisheries Institute, the Mississippi Chapter of the American Fisheries Society, and the Lytle Scholarship and Tom McIllwain Scholarship of the University of Southern Mississippi.

\section{Literature cited}

Acero P., A., D. Bustos-Montes, P. Pabón Quintero, C. J. Polo-Silva, and A. Sanjuan Muńoz.

2019. Feeding habits of Pterois volitans: a real threat to Caribbean coral reef biodiversity. In Impacts of invasive species on coastal environments: coasts in crisis (C. Makowski and C. W. Finkl, eds.), p. 269-314. Springer Intl. Publ., Cham, Switzerland.

Aguilar-Perera, A., and A. Tuz-Sulub.

2010. Non-native, invasive red lionfish (Pterois volitans [Linnaeus, 1758]: Scorpaenidae), is first recorded in the southern Gulf of Mexico, off the northern Yucatan Peninsula, Mexico. Aquat. Invasions 5:S9-S12. Crossref

Albins, M. A.

2015. Invasive Pacific lionfish Pterois volitans reduce abundance and species richness of native Bahamian coral-reef fishes. Mar. Ecol. Prog. Ser. 522:231-243. Crossref

Barbour, A. B., M. L. Montgomery, A. A. Adamson, E. DíazFerguson, and B. R. Silliman.

2010. Mangrove use by the invasive lionfish Pterois volitans. Mar. Ecol. Prog. Ser. 401:291-294. Crossref

Barbour, A. B., M. S. Allen, T. K. Frazer, and K. D. Sherman.

2011. Evaluating the potential efficacy of invasive lionfish (Pterois volitans) removals. PLoS ONE 6(5):e19666. Crossref
Barker, B. D., A. Z. Horodysky, and D. W. Kerstetter.

2018. Hot or not? Comparative behavioral thermoregulation, critical temperature regimes, and thermal tolerances of the invasive lionfish Pterois sp. versus native western North Atlantic reef fishes. Biol. Invasions 20:45-58. Crossref

Beck, M. W.

2003. The sea around: conservation planning in marine regions. In Drafting a conservation blueprint: a practitioner's guide to planning for biodiversity (G. R. Groves, ed.), p. 319-344. Island Press, Washington, D.C.

Beck, M. W., and M. Odaya.

2001. Ecoregional planning in marine environments: identifying priority sites for conservation in the northern Gulf of Mexico. Aquat. Conserv. 11:235-242. Crossref

Benkwitt, C. E.

2013. Density-dependent growth in invasive lionfish (Pterois volitans). PLoS ONE 8(6):e66995. Crossref

2015. Non-linear effects of invasive lionfish density on native coral-reef fish communities. Biol. Invasions 17:1383-1395. Crossref

Benkwitt, C. E., M. A. Albins, K. L. Buch, K. E. Ingeman, T. L. Kindinger, T. J. Pusack, C. D. Stallings, and M. A. Hixon.

2017. Is the lionfish invasion waning? Evidence from the Bahamas. Coral Reefs 36:1255-1261. Crossref

Berkeley, S. A., M. A. Hixon, R. J. Larson, and M. S. Love.

2004. Fisheries sustainability via protection of age structure and spatial distribution of fish populations. Fisheries 29(8):23-32. Crossref

Bilgin, S., and E. Ş. Çelik.

2009. Age, growth and reproduction of the black scorpionfish, Scorpaena porcus (Pisces, Scorpaenidae), on the Black Sea coast of Turkey. J. Appl. Ichthyol. 25:55-60. Crossref

Boehlert, G. W., and R. F. Kappenman.

1980. Variation of growth with latitude in two species of rockfish (Sebastes pinniger and S. diploproa) from the northeast Pacific Ocean. Mar. Ecol. Prog. Ser. 3:1-10. Crossref

Brown-Peterson, N. J., and J. R. Hendon.

2013. Notes on the biology of invasive lionfish (Pterois spp.) from the northcentral Gulf of Mexico. Gulf Caribb. Res. 25:117-120. Crossref

Brunel, T., and G. J. Piet.

2013. Is age structure a relevant criterion for the health of fish stocks? ICES. J. Mar. Sci. 70:270-283. Crossref

Chagaris, D., S. Binion-Rock, A. Bogdanoff, K. Dahl, J. Granneman, H. Harris, J. Mohan, M. B. Rudd, M. K. Swenarton, R. Ahrens, et al.

2017. An ecosystem-based approach to evaluating impacts and management of invasive lionfish. Fisheries 42(8): 421-431. Crossref

Choat, J. H., and L. M. Axe.

1996. Growth and longevity in acanthurid fishes; an analysis of otolith increments. Mar. Ecol. Prog. Ser. 134:15-26 Crossref

Claydon, J. A. B., M. C. Calosso, and S. B. Traiger.

2012. Progression of invasive lionfish in seagrass, mangrove and reef habitats. Mar. Ecol. Prog. Ser. 448:119-129. Crossref

Copp, G. H., and M. G. Fox.

2007. Growth and life history traits of introduced pumpkinseed (Lepomis gibbosus) in Europe, and the relevance to its potential invasiveness. In Biological invaders in inland waters: profiles, distribution, and threats (F. Gherardi, ed.), p. 289-306. Springer, Dordrecht, Netherlands.

Côté, I. M., and N. S. Smith.

2018. The lionfish Pterois sp. invasion: has the worst-case scenario come to pass? J. Fish Biol. 92:660-689. Crossref 
Crooks, J. A., and M. E. Soulé.

1999. Lag times in population explosions of invasive species: causes and implications. In Invasive species and biodiversity management (O. T. Sandland, P. J. Schei, and Å. Viken, eds.), p.103-125. Kluwer Acad. Publ., Dordrecht, Netherlands.

Curtis, J. S., K. R. Wall, M. A. Albins, and C. D. Stallings.

2017. Diet shifts in a native mesopredator across a range of invasive lionfish biomass. Mar. Ecol. Prog. Ser. 573: 215-228. Crossref

Dahl, K. A., and W. F. Patterson III.

2014. Habitat-specific density and diet of rapidly expanding invasive red lionfish, Pterois volitans, populations in the northern Gulf of Mexico. PLoS ONE 9(8):e105852. Crossref

Dahl, K. A., W. F. Patterson III, and R. A. Snyder.

2016. Experimental assessment of lionfish removals to mitigate reef fish community shifts on northern Gulf of Mexico artificial reefs. Mar. Ecol. Prog. Ser. 558:207-221. Crossref

Darling, E. S., S. J. Green, J. K. O'Leary, and I. M. Côté.

2011. Indo-Pacific lionfish are larger and more abundant on invaded reefs: a comparison of Kenyan and Bahamian lionfish populations. Biol. Invasions 13:2045-2051. Crossref

Dulvy, N. K., N. V. C. Polunin, A. C. Mill, and N. A. Graham.

2004. Size structural change in lightly exploited coral reef fish communities: evidence for weak indirect effects. Can. J. Fish. Aquat. Sci. 61:466-475. Crossref

Edwards, M. A., T. K. Frazer, and C. A. Jacoby.

2014. Age and growth of invasive lionfish (Pterois spp.) in the Caribbean Sea, with implications for management. Bull. Mar. Sci. 90:953-966. Crossref

Fogg, A. Q.

2017. Life history of the non-native invasive red lionfish (Pterois volitans) in the northern Gulf of Mexico. M.S. thesis, 160 p. Univ. South. Miss., Ocean Springs, MS.

Fogg, A. Q., and M. E. Faletti.

2018. Invasive lionfish (Pterois sp.) agonistic behavior observations. Bull. Mar. Sci. 94:1-2. Crossref

Fogg, A. Q., E. R. Hoffmayer, W. B. Driggers III, M. D. Campbell, G.

J. Pellegrin, and W. Stein.

2013. Distribution and length frequency of invasive lionfish (Pterois sp.) in the northern Gulf of Mexico. Gulf Caribb. Res. 25:111-115. Crossref

Fogg, A. Q., N. J. Brown-Peterson, and M. S. Peterson.

2017. Reproductive life history characteristics of invasive red lionfish (Pterois volitans) in the northern Gulf of Mexico. Bull. Mar. Sci. 93(3):791-813. Crossref

Frazer, T. K., C. A. Jacoby, M. A. Edwards, S. C. Barry, and C. M. Manfrino.

2012. Coping with the lionfish invasion: can targeted removals yield beneficial effects? Rev. Fish. Sci. 20:185-191. Crossref

Gadgil, M., and W. H. Bossert.

1970. Life historical consequences of natural selection. Am. Nat. 104:1-24. Crossref

García-Rivas, M. D. C., S. Machkour-M’Rabet, G. Pérez-Lachaud,

J. J. Schmitter-Soto, R. Céréghino, C. Doneys, N. St-Jean, and

Y. Hénaut.

2018. Age-dependent strategies related to lionfish activities in the Mexican Caribbean. Environ. Biol. Fish. 101: 563-578. Crossref

Graham, R. E., and L. M. Fanning.

2017. A comparison of eight country plans for the invasive Indo-Pacific lionfish in the wider Caribbean. Global Ecol. Conserv. 12:253-262. Crossref

Green, S. J., and I. M. Côté.

2009. Record densities of Indo-Pacific lionfish on Bahamian coral reefs. Coral Reefs 28:107. Crossref
Green, S. J., N. K. Dulvy, A. M. L. Brooks, J. L. Akins, A. B. Cooper, S. Miller, and I. M. Côté.

2014. Linking removal targets to the ecological effects of invaders: a predictive model and field test. Ecol. Appl. 24:1311-1322. Crossref

Green, S. J., E. B. Underwood, and J. L. Atkins.

2017. Mobilizing volunteers to sustain local suppression of a global marine invasion. Conserv. Lett. 10:726-735. Crossref

Hamner, R. M., D. W. Freshwater, and P. E. Whitfield.

2007. Mitochondrial cytochrome $b$ analysis reveals two invasive lionfish species with strong founder effects in the western Atlantic. J. Fish Biol. 71(sb):214-222. Crossref

Ingeman, K. E., and M. S. Webster.

2015. Native prey mortality increases but remains densitydependent following lionfish invasion. Mar. Ecol. Prog. Ser. 531:241-252. Crossref

Johnson, E. G., and M. K. Swenarton.

2016. Age, growth and population structure of invasive lionfish (Pterois volitans/miles) in northeast Florida using a length-based, age-structured population model. PeerJ 4:e2730. Crossref

Johnson, J., C. E. Bird, M. A. Johnston, A. Q. Fogg, and J. D. Hogan. 2016. Regional genetic structure and genetic founder effects in the invasive lionfish: comparing the Gulf of Mexico, Caribbean and North Atlantic. Mar. Biol. 163:216 Crossref

Johnston, M. A., S. R. Gittings, and J. A. Morris Jr.

2015. NOAA National Marine Sanctuaries lionfish response plan (2015-2018): responding, controlling, and adapting to an active marine invasion. NOAA Off. Mar. Sanctuaries, Mar. Sanctuaries Conserv. Ser. ONMS-15-01, 55 p. [Available from website.]

Johnston, M. W., A. M. Bernard, and M. S. Shivji.

2017. Forecasting lionfish sources and sinks in the Atlantic: are Gulf of Mexico reef fisheries at risk? Coral Reefs 36:169-181. Crossref

Jud, Z. R., C. A. Layman, J. A. Lee, and D. A. Arrington.

2011. Recent invasion of a Florida (USA) estuarine system by lionfish Pterois volitans / P. miles. Aquat. Biol. 13:21-26. Crossref

La Mesa, M., G. Scarcella, F. Grati, and G. Fabi.

2010. Age and growth of the black scorpionfish, Scorpaena porcus (Pisces: Scorpaenidae) from artificial structures and natural reefs in the Adriatic Sea. Sci. Mar. 74:677-685. Crossref

Lindsey, C. C.

1966. Body sizes of poikilotherm vertebrates at different latitudes. Evolution 20:456-465. Crossref

Lyons, T. J., Q. M. Tuckett, and J. E. Hill.

2017. Lower lethal temperatures for two commonly traded species of lionfishes: implications for establishment beyond Pterois volitans and P. miles. Copeia 105:630-633. Crossref

Meister, H. S., D. M. Wyanski, J. K. Loefer, S. W. Ross, A. M. Quattrini, and K. J. Sulak.

2005. Further evidence for the invasion and establishment of Pterois volitans (Teleostei: Scorpaenidae) along the Atlantic coast of the United States. Southeastern Nat. 4:193-206. Crossref

Mizrahi, M., J. K. Chapman, C. L. A. Gough, F. Humber, and L. G. Anderson.

2017. Management implications of the influence of biological variability of invasive lionfish diet in Belize. Manage. Biol. Invasions 8:61-70. Crossref

Morris, J. A., Jr., and J. L. Akins.

2009. Feeding ecology of invasive lionfish (Pterois volitans) in the Bahamian archipelago. Environ. Biol. Fish. 86:389-398. Crossref 
Nelson, R. S., and C. S. Manooch III.

1982. Growth and mortality of red snappers in the westcentral Atlantic Ocean and northern Gulf of Mexico. Trans. Am. Fish. Soc. 111:465-475. Crossref

Parker, G. A. 1992. The evolution of sexual size dimorphism in fish. J. Fish. Biol. 41(sB):1-20. Crossref

Pasko, S., and J. Goldberg.

2014. Review of harvest incentives to control invasive species. Manage. Biol. Invasions 5:263-277. Crossref

Pearson, D. E.

1996. Timing of hyaline-zone formation as related to sex, location, and year of capture in otoliths of the widow rockfish, Sebastes entomelas. Fish. Bull. 94:190-197.

Pitcher, T. J., and P. J. B. Hart. 1982. Fisheries ecology, 414 p. Croon Helm Ltd., London.

Potts, J. C., D. Berrane, and J. A. Morris Jr. 2010. Age and growth of lionfish from the western North Atlantic. Proc. Gulf Caribb. Fish. Inst. 63:314. [Available from website.]

Pusack, T. J., C. E. Benkwitt, K. Cure, and T. L. Kindinger.

2016. Invasive red lionfish (Pterois volitans) grow faster in the Atlantic Ocean than in their native Pacific range. Environ. Biol. Fish. 99571-579. Crossref

Reznick, D.

1983. The structure of guppy life histories: the tradeoff between growth and reproduction. Ecology 64:862-873. Crossref

Robertson, D. R., and K. L. Cramer.

2014. Defining and dividing the Greater Caribbean: insights from the biogeography of shorefishes. PLoS ONE 9(7): e102918. Crossref

Rocha, L. A., C. R. Rocha, C. C. Baldwin, L. A. Weigt, and M. McField. 2015. Invasive lionfish preying on critically endangered reef fish. Coral Reefs 34:803-806. Crossref

Rodríguez-Cortés, K.D.,A.Aguilar-Perera, and J.L.Bonilla-Gómez. 2015. Growth and mortality of red lionfish, Pterois volitans (Actinopterygii: Scorpaeniformes: Scorpaenidae), in the Parque Nacional Arrecife Alacranes, southern Gulf of Mexico, as determined by size-frequency analysis. Acta Ichthyol. Piscat. 45:175-179. Crossref

Roff, D. A.

1983. An allocation model of growth and reproduction in fish. Can. J. Fish. Aquat. Sci. 40:1395-1404. Crossref

Rojas-Vélez, S., J. Tavera, and A. Acero.

2019. Unraveling lionfish invasion: Is Pterois volitans truly a morphologically novel predator in the Caribbean? Biol. Invasions 21:1921-1931. Crossref

Ruttenberg, B. I., A. J. Haupt, A. I. Chiriboga, and R. R. Warner. 2005. Patterns, causes and consequences of regional variation in the ecology and life history of a reef fish. Oecologia 145:394-403. Crossref

Ruttenberg, B. I., P. J. Schofield, J. L. Akins, A. Acosta, M. W.

Feeley, J. Blondeau, S. G. Smith, and J. S. Ault.

2012. Rapid invasion of Indo-Pacific lionfishes (Pterois volitans and Pterois miles) in the Florida Keys, USA: evidence from multiple pre- and post-invasion data sets. Bull. Mar. Sci. 88:1051-1059. Crossref

Sabido-Itzá, M. M., A. Medina-Quej, A. Jesús-Navarrete, J. M. Gómez-Poot, and M. C. García-Rivas.

2016. Size structure as evidence of population establishment of Pterois volitans (Scorpaeniformes: Scorpaenidae) in the South Mexican Caribbean. Rev. Biol. Trop. 64:353-362. Crossref

Schabenberger, O., and F. J. Pierce.

2002. Nonlinear Models. In Contemporary statistical models for the plant and soil sciences, p. 183-293. CRC Press, Boca Raton, FL.
Schofield, P. J.

2010. Update on geographic spread of invasive lionfishes (Pterois volitans [Linnaeus, 1758] and P. miles [Bennett, 1828]) in the Western North Atlantic Ocean, Caribbean Sea and Gulf of Mexico. Aquat. Invasions 5:S117-S122. Crossref

Secor, D. H., Dean J. M., and E. H. Laban.

1991. Manual for otolith removal and preparation for microstructural examination. Belle W. Baruch Inst. Mar. Biol. Coast. Res. Tech. Publ. 1991-01, 85 p.

Shine, $\mathrm{R}$.

1989. Ecological causes for the evolution of sexual dimorphism: a review of the evidence. Q. Rev. Biol. 64:419-461. Crossref

South, J., J. T. A. Dick, M. McCard, D. Barrios-O'Neill, and A. Anton.

2017. Predicting predatory impact of juvenile invasive lionfish (Pterois volitans) on a crustacean prey using functional response analysis: effects of temperature, habitat complexity and light regimes. Environ. Biol. Fish. 100:1155-1165. Crossref

Spalding, M. D., H. E. Fox, G. R. Allen, N. Davidson, Z. A. Ferdaña, M. Finlayson, B. S. Halpern, M. A. Jorge, A. Lombana, S. A. Lourie, et al.

2007. Marine ecoregions of the world: a bioregionalization of coastal and shelf areas. BioScience 57:573-583. Crossref

Sullivan Sealey, K., and G. Bustamante.

1999. Setting geographic priorities for marine conservation in Latin America and the Caribbean, 125 p. Nat. Conserv., Arlington, VA. [Available from website.]

Swenarton, M., E. G. Johnson, and L. Akins.

2015. Regional comparisons of lionfish (Pterois spp.) population demographics from the east coast of Florida. Proc. Gulf Caribb. Fish. Inst. 67:215-216. [Available from website.]

Tamburello, N., and I. M. Côté.

2015. Movement ecology of Indo-Pacific lionfish on Caribbean coral reefs and its implications for invasion dynamics. Biol. Invasions 17:1639-1653. Crossref

Tanaka, K., Y. Mugiya, and J. Yamada.

1981. Effects of photoperiod and feeding on daily growth patterns in otoliths of juvenile Tilapia nilotica. Fish. Bull. 79:459-466.

Tobin, A., L. Currey, and C. Simpfendorfer.

2013. Informing the vulnerability of species to spawning aggregation fishing using commercial catch data. Fish. Res. 143:47-56. Crossref

Villaseñor-Derbez, J. C., and S. Fitzgerald.

2019. Spatial variation in allometric growth of invasive lionfish has management implications. PeerJ 7:e6667. Crossref

White, D. B., D. M. Wyanski, and G. R. Sedberry.

1998. Age, growth, and reproductive biology of the blackbelly rosefish from the Carolinas, U.S.A. J. Fish Biol. 53: 1274-1291. Crossref

Yáñez-Arancibia, A., and J. W. Day.

2004. Environmental sub-regions in the Gulf of Mexico coastal zone: the ecosystem approach as an integrated management tool. Ocean Coast. Manage. 47:727-757. Crossref

Zhou, S., A. D. M. Smith, A. E. Punt, A. J. Richardson, M. Gibbs, E. A. Fulton, S. Pascoe, C. Bulman, P. Bayliss, and K. Sainsbury. 2010. Ecosystem-based fisheries management requires a change to the selective fishing philosophy. Proc. Natl. Acad. Sci. U.S.A. 107:9485-9489. Crossref 